\title{
Fatal pulmonary thromboembolism associated with hemoglobin SC disease in a 15 year-old boy
}

\author{
Thiago Trolez Amancio ${ }^{a}$, Anderson da Costa Lino Costa ${ }^{a}$, Marcela Longo Borsato ${ }^{a}$,

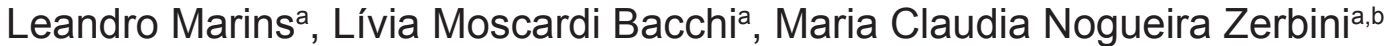

Amancio TT, Costa ACL, Borsato ML, Marins L, Bacchi LM, Zerbini MCN. Fatal pulmonary thromboembolism associated with hemoglobin SC disease in a 15 year-old boy. Autopsy Case Rep [Internet]. 2011;1(3):15-22. http://dx.doi.org/10.4322/acr.2011.004

\section{ABSTRACT}

We report a case of hemoglobin SC disease complicated by fatal pulmonary thromboembolism in a 15 year-old Brazilian boy, submitted to autopsy. This case shows the importance of early diagnosis and treatment of sickle cell disease, which generates systemic involvement in youth and the importance of considering the hypercoagulability in these patients. The autopsy was very instructive, revealing the florid morphologic aspect of sickle cell disease and its complications.

Keywords: Autopsy; Hemoglobin SC disease; Thromboembolism; Sickle hemoglobin.

\section{CLINICAL SUMMARY}

A 15 year-old Brazilian male with diagnosis of Hemoglobin SC disease, confirmed by hemoglobin electrophoresis (Table 1) was admitted to the emergency room complaining of severe left hip pain, accompanied by local hyperemia and movement limitation. He reported daily fever of 38 to $39{ }^{\circ} \mathrm{C}$ for the last 11 days. The patient had a past history of surgery due to avascular necrosis of the left femoral head 5 years ago.

His phisycal examination nothing added to the patient's complaints. Ultrasonography of the hips showed signs of joint effusion and synovial thickening in the left hip. Laboratory tests on admission are shown in Table 2.

Abdominal ultrasonography revealed a slightly enlarged liver and billiary tract without signs of cholecistopathy. Spleen was not visualized.
Total abdominal and pelvic computed tomography scan revealed deformity of femoral heads, subchondral cysts and sclerosis, more pronounced on the right. There was a tubular bone defect in the left femoral neck, probably due to prior orthopedic surgery. Bilateral hip joint effusion was present, being greater on the left. Hepatomegaly and a normal-sized spleen, presenting multiple hypodense nodules, probably solids, measuring up to $2.0 \mathrm{~cm}$. Biliary tract, pancreas, adrenals, kidneys, bladder and aorta were normal.

A left hip arthrocentesis was performed, with drainage of a dark brown fluid. Septic artrithis was suspected. The pacient was prescribed oxacillin and gentamicin and an emergency surgery for debridement and drainage on the left hip was performed.

\footnotetext{
a Departamento de Patologia da Faculdade de Medicina - Universidade de São Paulo, São Paulo/SP - Brazil.

b Serviço de Anatomia Patológica do Hospital Universitário - Universidade de São Paulo, São Paulo/SP - Brazil.
}

Copyright (c) 2011 Autopsy and Case Reports - This is an Open Access article distributed of terms of the Creative Commons Attribution NonCommercial License (http://creativecommons.org/licenses/by/3.0/) which permits unrestricted non-commercial use, distribution, and reproduction in any médium provided article is properly cited. 
Synovial fluid analysis showed no microorganisms on bacterioscopy neither its culture was positive for bacterial or fungus growth.

Two days after the surgery, he presented acute dyspnea and abdominal pain. On examination, the patient was tachycardic, hypotensive and tachydyspneic, showing oxymetry $72 \%$, evolving to cardiac arrest.

Table 1 - Hemoglobin electroforesis

\begin{tabular}{lr}
\hline \multicolumn{2}{c}{ Abnormal values are highlighted } \\
\hline Hemoglobin A: (\%) & 0.0 \\
Hemoglobin C: (\%) & 48.5 \\
Hemoglobin S: (\%) & $\mathbf{5 0 . 5}$ \\
Hemoglobin F: (\%) & 1.0 \\
\hline
\end{tabular}

Presence of Hemoglobin SC. Osmotic resistance in $\mathrm{NaCl} 0,36 \%$ positive.

\section{AUTOPSY FINDINGS}

On external examination, the anthropometric measures revealed the body of a young man with $170 \mathrm{~cm}$ of heigh, weighting $46 \mathrm{~kg}$, showing acrocyanosis, pale mucous membranes and mild jaundice. A recent surgical scar of $10 \mathrm{~cm}$ on the left thigh was seen, where a small hematoma and necrotic tissue were enclosed. No pus was found.

Right and left lungs weighed 256 and $234 \mathrm{~g}$ (normal: 325 to $570 \mathrm{~g}$ ) ${ }^{*}$ respectively. The external surface was smooth, gray with anthracotic deposits. On sectioning, the parenchyma was aerated, had spongy consistency, reddish colour and crepitation was preserved (Figure 1A). There were multiple thrombi and blood clots in the pulmonary vessels in all lobes, bilaterally (Figure 1B). No pleural effusion

* Finkbeiner WE, Ursell PC, Davis RL. Autopsy pathology: a manual and atlas. 2nd ed.; p. 333-5.

Table 2 - Laboratory data on admission

\begin{tabular}{|c|c|c|c|}
\hline Exam & Unit & Value & RV \\
\hline CC-reactive protein & $m g \cdot L^{-1}$ & 331.4 & $<5.0$ \\
\hline Fibrinogen & $\mathrm{mg} \cdot \mathrm{dL}^{-1}$ & 1652.0 & $16.0-465.0$ \\
\hline AST & U. $L^{-1}$ & 24.0 & $10.0-36.0$ \\
\hline ALT & U. $L^{-1}$ & 25.0 & $24.0-59.0$ \\
\hline Sodium & $\mathrm{mEq} \cdot \mathrm{L}^{-1}$ & 135.0 & $135.0-145.0$ \\
\hline Potassium & $\mathrm{mEq} \cdot \mathrm{L}^{-1}$ & 4.8 & $3.5-5.0$ \\
\hline Creatinine & $m g \cdot d L^{-1}$ & 0.6 & $0.39-0.87$ \\
\hline Urea & $m g \cdot d L^{-1}$ & 22.0 & $10.0-45.0$ \\
\hline Hemoblobin & $g \%$ & 9.0 & $14.4-16.6$ \\
\hline Hematocrit & $\%$ & 25.6 & $43.0-49.0$ \\
\hline MCV & $\mathrm{fL}$ & 76.9 & $86.0-94.0$ \\
\hline $\mathrm{MCH}$ & pg & 27.0 & $28.0-32.0$ \\
\hline Leukocytes & $\mathrm{mm}^{3}$ & 14790.0 & $4,5-12,0$ \\
\hline Neutrophil & $\%$ & 63.3 & $53.0-57.0$ \\
\hline Eosinophils & $\%$ & 0.7 & $2.5-2.6$ \\
\hline Lymphocytes & $\%$ & 29.5 & $35.0-37.0$ \\
\hline Monocytes & $\%$ & 6.2 & 0.0 \\
\hline Platellets & $\mathrm{mm}^{3}$ & 1235000.0 & $140000.0-450000.0$ \\
\hline APTT & $\mathbf{s}$ & 56.7 & 29.5 \\
\hline INR & & 1.28 & \\
\hline
\end{tabular}

(Abnormal values are highlighted), $\mathrm{RV}=$ reference value, $\mathrm{AST}=$ aspartate transaminase, $\mathrm{ALT}=$ alanine transaminase, $\mathrm{MCV}=$ mean corpuscular volume, $\mathrm{MCH}=$ mean corpuscular hemoglobin, APTT = activated partial thromboplastin time, INR = international normalized. 

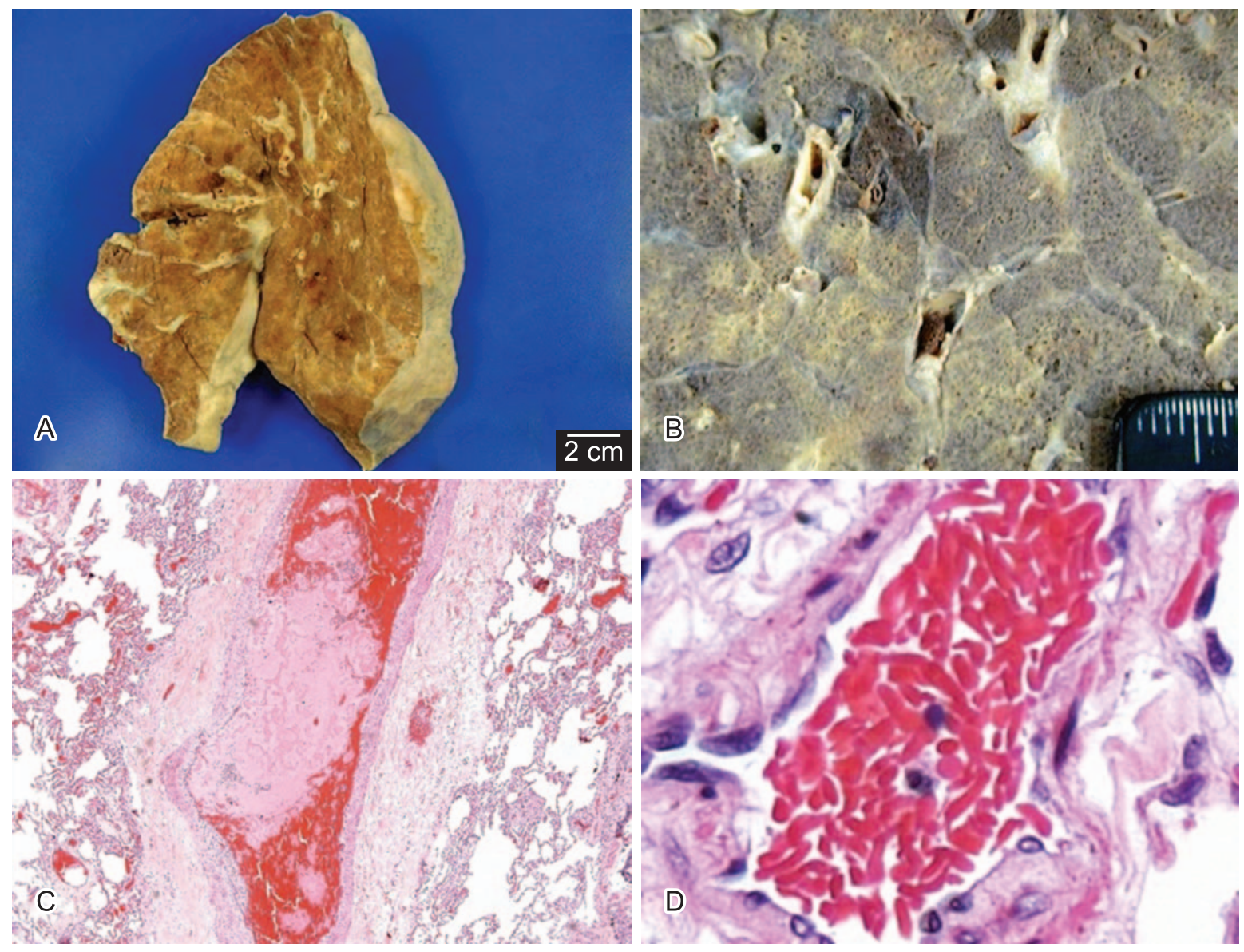

Figure 1 - A - Right lung (inside view); B - Thrombi in pulmonary vessels (close view); C - Photomicrography - Thrombus in pulmonary vessel (H\&E, 50X); D - Photomicrography - Sickle red blood cells in pulmonary vessels (H\&E, 400X).

was detected. Histological examination confirmed pulmonary thromboembolism and revealed old and recent thrombi in pulmonary vessels (Figure 1C) and areas of pulmonary hemorrhagic infarction. Sickled red blood cells were observed (Figure 1D). There were not signs of pulmonary hypertension or inflammatory exudates.

Spleen was decreased in size and volume, weighting $72 \mathrm{~g}$ (normal: 150 to $200 \mathrm{~g}$ ), with a smooth and purplish capsule. On sectioning, the parenchyma was congested, with hard consistency and multiple fibrotic whitish spots. Multiple well circunscribed congested/ hemorrhagic nodules, dark red, soft, measuring up to $2 \mathrm{~cm}$ were observed (Figures $2 \mathrm{~A}$ and 2B). Histological examination revealed a depleted white pulp, multiple old and recent infarcts (Figure $2 \mathrm{C}$ and $2 \mathrm{D}$ ), with areas of fibrosis (Figure $3 \mathrm{C}$ ), hemorrhage, calcification, hemosiderin deposition (Figure 3D) and GamnaGandy bodies. (Figure 3B) The nodules described on gross examination were represented by more preserved congested areas (Figure $3 \mathrm{~A}$ ).
The brain weighed $1310 \mathrm{~g}$ (normal: $1410 \mathrm{~g}$ ), and showed cortical edema and congested vessels, filled with sickled erythrocytes.

The liver weighed $2144 \mathrm{~g}$ (normal: 1500 to $1800 \mathrm{~g}$ ), presenting congestion, with the presence of sickled red blood cells and a slight portal lymphocytic infiltrate. (Figure 4A and 4B).

Right and left kidneys weighed 170 and $192 \mathrm{~g}$ (normal: 115 to $220 \mathrm{~g}$ ), respectively. The capsule was easily detached and showed smooth and gray outer surface. On sectioning, there were no lesions. Histology showed glomerular and vascular congestion with sickled erytrocytes (Figure 5A and 5B).

The bone marrow was hypercellular (approximately $90 \%$ of hematopoietic cells), with increase of both erythroid and myeloid lines. Sinusoids were congested, containing sickled red cells (Figure 6). 

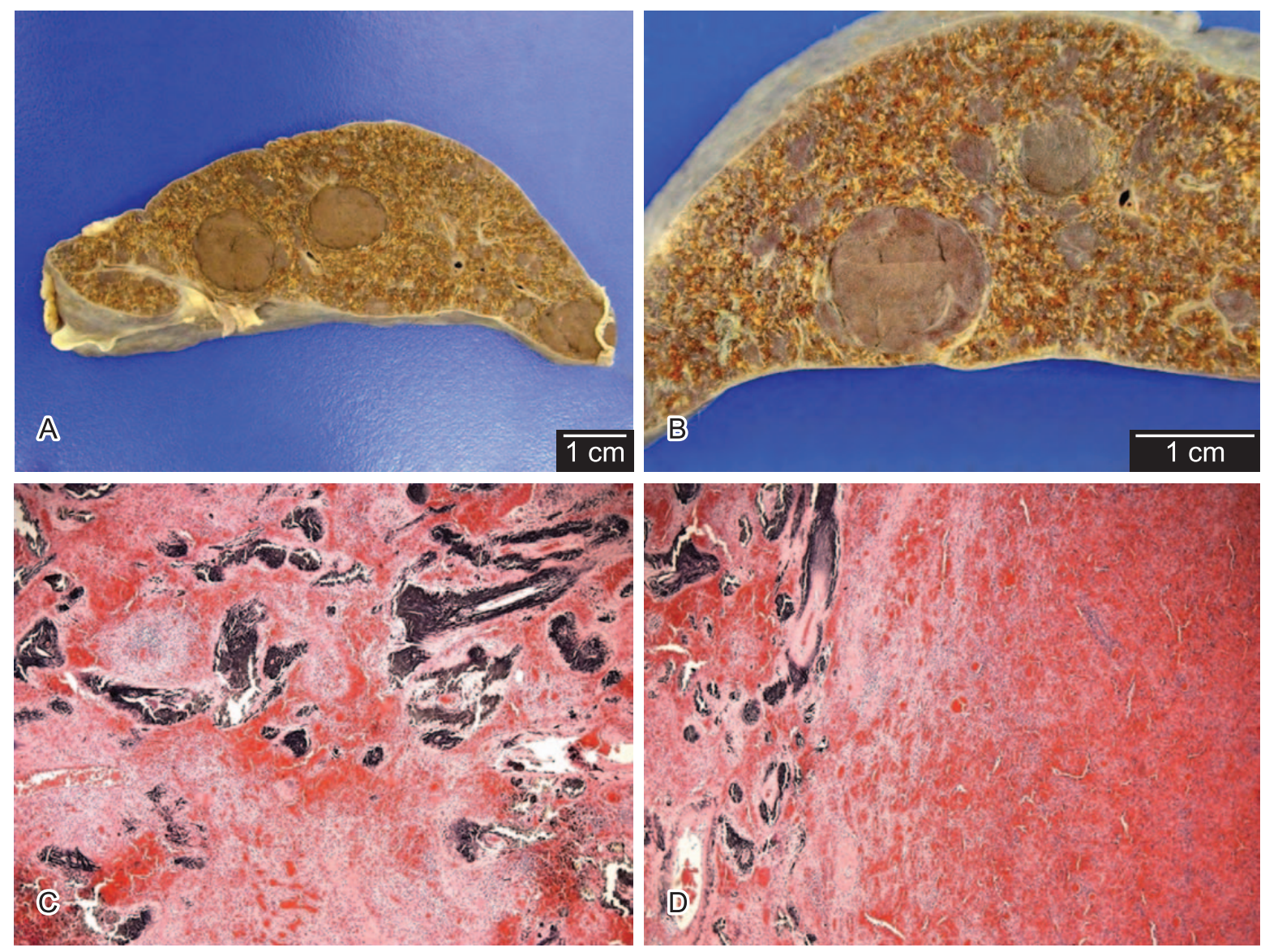

Figure 2 - A, B - Splenic parenchyma with multiple fibrotic whitish spots (iron deposits) and well circumscribed congested/ hemorrhagic nodules; C - Photomicrography - Splenic parenchyma with decrease in white pulp, areas of fibrosis, hemorrhage, calcification and hemosiderin deposition (H \& E, 50X); D - Photomicrography Transition between the splenic parenchyma and the well defined congested/ hemorrhagic areas (H \& E, 50X).

The examination of esophagus, stomach, pancreas, small and large intestine, adrenal glands, bladder, prostate, gall bladder, thyroid and testicles was unremarkable.

The reserch for deep venous thrombosis was confined to territory of the iliac and femoral veins, wich failed to demonstrate thrombi presence.

\section{DISCUSSION}

We report a case of hemoglobin SC disease disease complicated by fatal pulmonary thromboembolism in a 15 year-old Brazilian boy, submitted to autopsy.

It has been estimated that approximately $7 \%$ of the world population are carriers of inherited haemoglobin disorders. The structural haemoglobin variants result from single amino-acid substitutions in the alfa or beta chains. ${ }^{1,2}$
Sickle cell disease (SCD) is a generic term that comprises a group of hereditary hemolytic anemia characterized by the production of hemoglobin $\mathrm{S}(\mathrm{HbS})$. The diagnosis is based on the analysis of hemoglobin by electrophoresis or chromatography. ${ }^{3-5}$

$\mathrm{HbS}$ is caused by a mutation in the $\beta$-globin gene in which the sixth aminoacid in the $\beta$-globin chain becomes valine instead of glutamic acid. $\mathrm{HbC}$ is also caused by a mutation in the beta chain, resulting in the substitution of glutamic acid by lysine..$^{2-4,6,7}$

Hemoglobin $\mathrm{HbS}$ shows peculiar biochemical properties, which leads to polymerization when deoxygenated. HbS polymerization leads to sickling of red blood cells. This process alters the cell membrane properties, which reduce cellular flexibility and lead to enhanced cell adherence to vascular endothelium. ${ }^{4,7}$ 

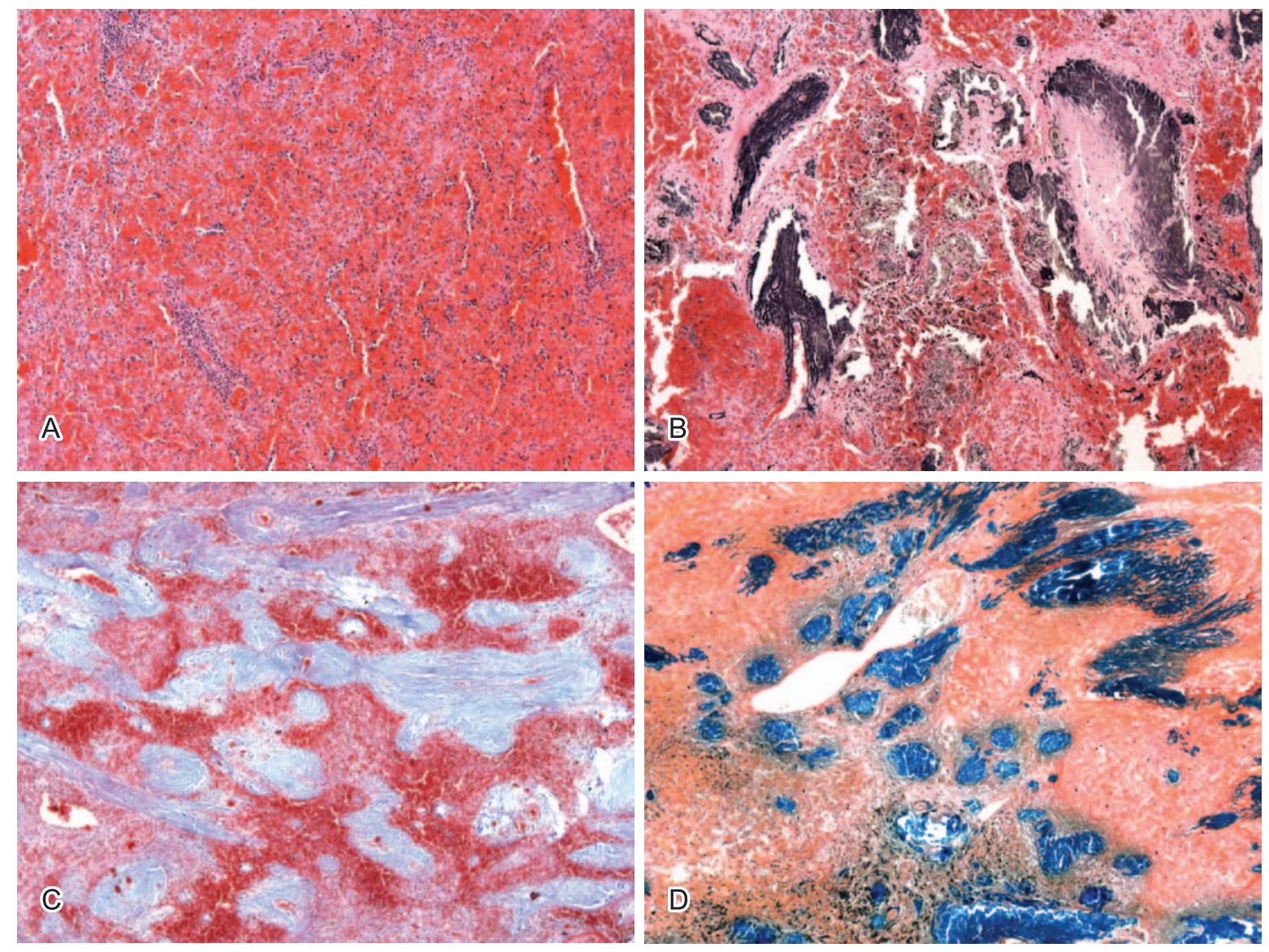

Figure 3 - Photomicrographs: A - Histological aspect of the well circumscribed congested/ hemorrhagic area. (H \& E, 100X); B - Gamna-Gandy bodies (H \& E, 200X); C - Splenic parenchyma with areas of fibrosis (blue) (Masson, 200X); D - Splenic parenchyma with hemosiderin deposition (blue) (Perls, 100X).
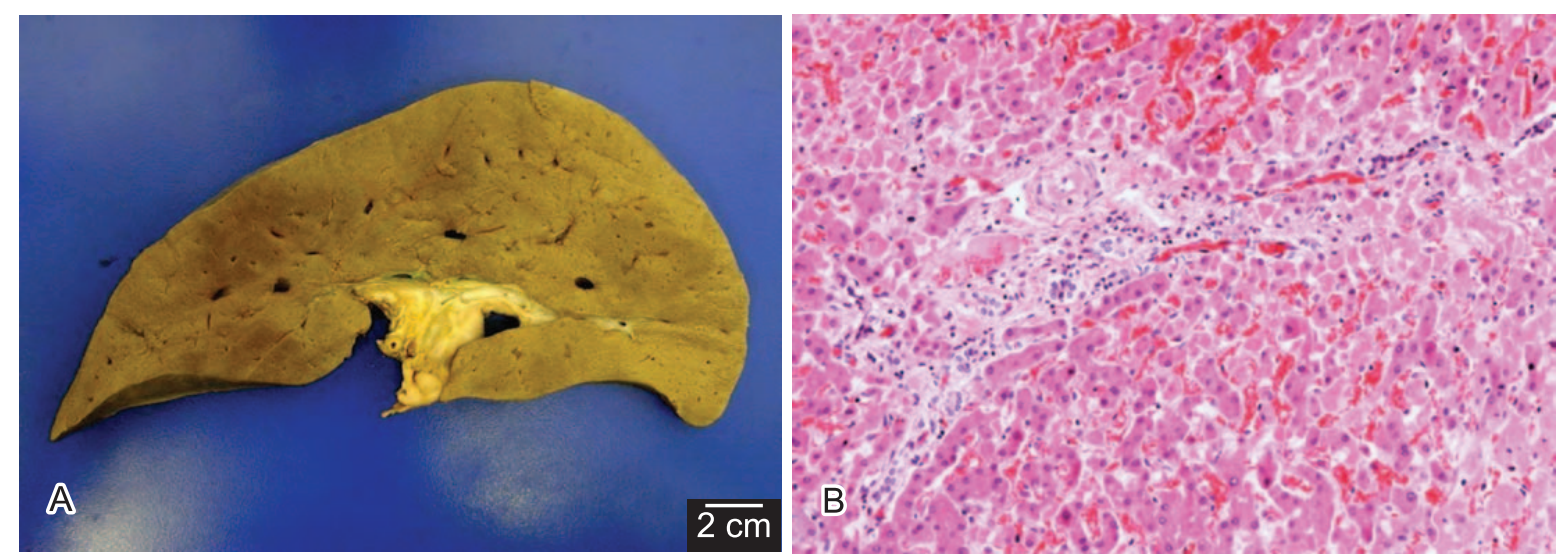

Figure 4 - A - Macroscopic aspect of liver; B - Hepatic congestion with the presence of sickle red blood cells and a slight lymphocytic infiltrate in portal tract (H \& E, 200X).

The presence of hemoglobin $\mathrm{HbC}$ in erytrocytes increases the intracellular hemoglobin concentration by loss of water and $\mathrm{K}^{+}$. This process increases the tendency of $\mathrm{HbS}$ to polymerize. ${ }^{8}$

The most common form of SCD is sickled cell anemia, caracterized by homozygosity for the $\beta$ S allele (HbSS). Hemoglobin SC disease (HbSC) is characterized by equal concentrations of $\mathrm{HbS}$ and $\mathrm{HbC}$, as in the present case. Individuals with $\mathrm{HbSC}$ are at risk for the same life-threatening complications as HbSS but at a decreased tendency. A small subset of HbSC patients has a clinical phenotype similar to HbSS (as it seems to 

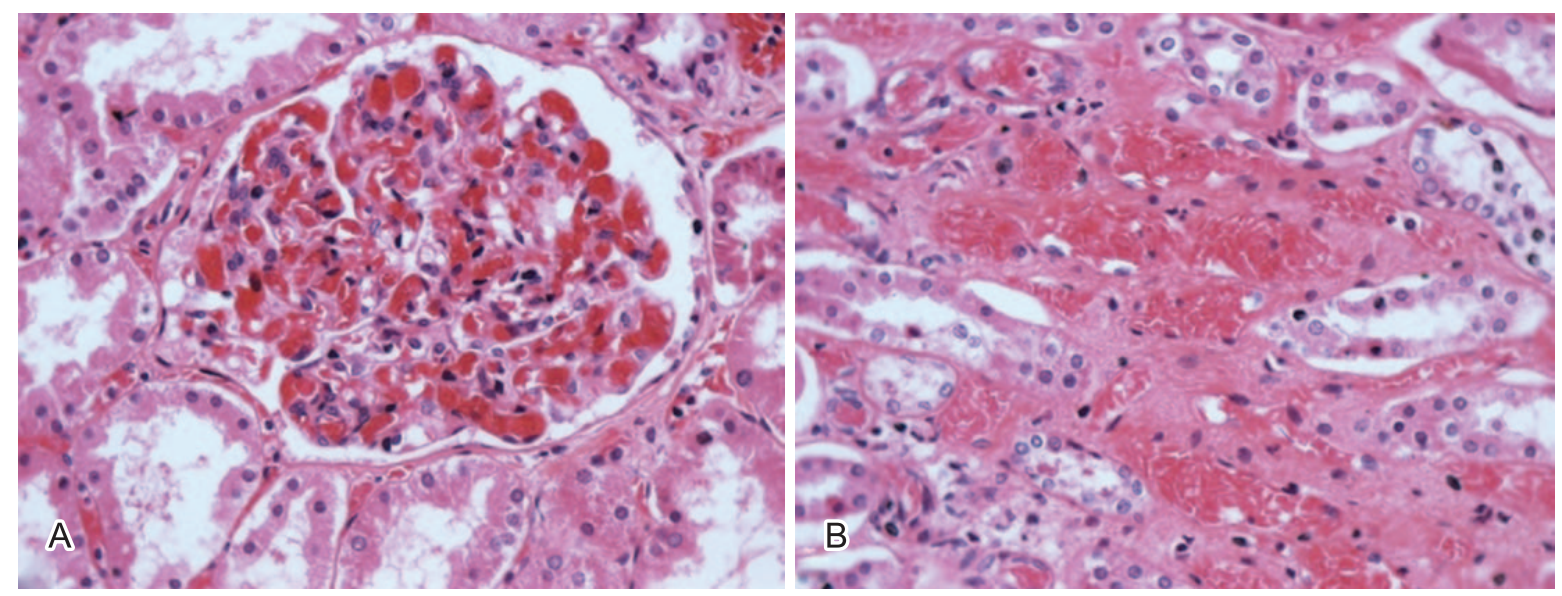

Figure 5 - Photomicrographs: A - Glomerular congestion (H \& E, 400X); B - Congested renal vessels with sickle erytrocytes in the renal medulla. (H \& E, 400X).

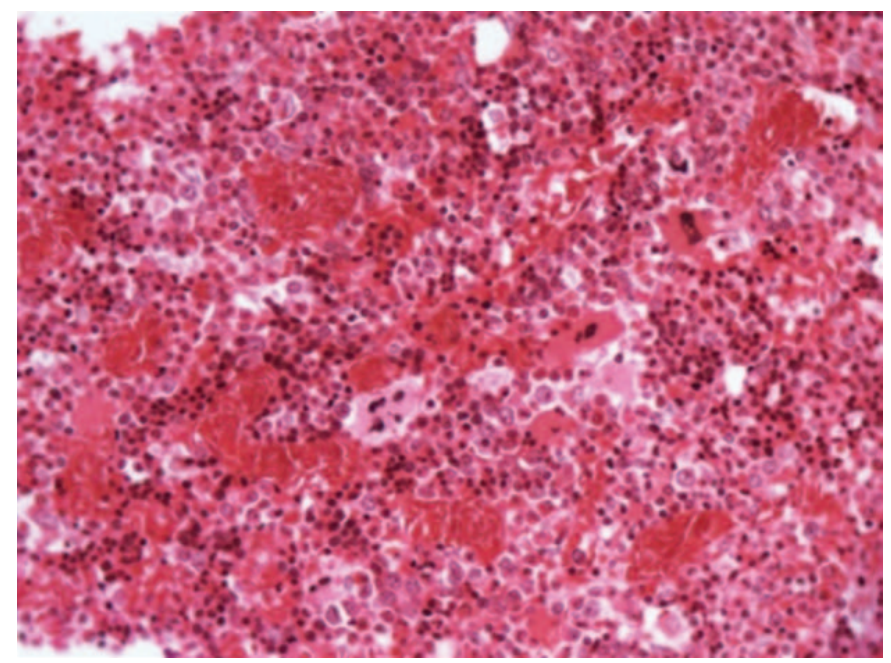

Figure 6 - Photomicrography - Hypercellular bone marrow with increased erythroid precursors and granulocytic lineage cells. Presence of congested vessels containing sickle erythrocytes. (H\& E, 400X).

be the case of this pacient). It is associated with important complications, including aseptic necrosis of the femoral or humeral heads, haematuria, proliferative retinopathy, and a thrombotic tendency. ${ }^{2,8}$

The pathophysiologic hallmark of SCD is episodic occurrence of vasoocclusive events that precipitate acute painful episodes. These recurrent episodes of ischaemia and inflammation result in progressive damage to the brain, kidneys, lungs, bones, cardiovascular system resulting in organic failures and death. These ischemic episodes are often followed by restoration of blood flow, which promotes tissue injury, caused by oxidant stress. ${ }^{6,9-11}$
The occlusive events within the microcirculation result from a complex scenario involving the interactions between dense dehydrated sickle cells, platelets, reticulocytes, abnormally activated endothelial cells, leukocytes, plasma factors, cytokines and oxidized pro-inflammatory lipids. ${ }^{12,13}$

Other important pathologic mechanism involves the release of haemoglobin into the circulation during intravascular hemolysis. The released hemoglobin produces reactive oxygen species, which is a potent scavenger of nitric oxide, causing vasoconstriction. Furthermore, the hemoglobin release inhibits endothelial nitric oxide signalling, leading to endothelial cell dysfunction and nitric oxide resistance. ${ }^{6,7}$

In patients with sickle cell disease there is a hypercoagulable state due to high levels of thrombin, abnormal activation of fibrinolysis, decreased levels of anticoagulant proteins, activation of platelets and increased circulating levels of soluble tissue factor. ${ }^{3,14,15}$

The painful vasoocclusive crises and osteomyelitis represent the most frequent complications requiring hospital admissions among patients with SCD. Other common complications are: funcional asplenia, splenic sequestration, acute chest syndrome (ACS), osteonecrosis (avascular necrosis), septic arthritis, dactylitis, cerebral infarcts, pulmonary hypertension, pulmonary embolism, renal infarction with papillary necrosis, renal medullary fibrosis with focal segmental glomerulosclerosis, retinopathy, thrombotic strokes, leg ulcers, fatigue, and cholelithiasis. $6,12,16,17$ 
In this case, the patient although young, already had severe complications related to SCD, such as osteonecrosis, functional asplenia and suspected septic arthritis. In patients with SCD, the spleen is almost always affected by microinfarcts, resulting in hyposplenism or asplenism. ${ }^{18}$

The aspect of spleen results from recurrent episodes of ischemic/inflammatory insults and intrasplenic hemolysis, culminating with fibroinflamatory reaction, deposition of calcium and hemossiderin. The well circumscribed round areas correspond to nodules of regeneration and consist of preserved and congested spleen parenchyma. The explanation for these pseudotumoral areas is still unknown. ${ }^{19-21}$

The most common cause of death for all sickle variants and for all age groups is infection/sepsis and death is frequently sudden and unexpected, as in the case reported. ${ }^{22}$

A large portion of the sudden death occurs beacause of pulmonary complications, like ACS, thromboembolism, pulmonary hypertension, lung edema and fat/bone marrow embolism. In our case, there was no clinical/radiologic information required for the diagnosis of ACS, wich is defined by a recent pulmonary infiltrate involving at least one complete lung segment, associated to a temperature of more than $38.5{ }^{\circ} \mathrm{C}$ or respiratory symptoms, like chest pain, tachypnea, wheezing or cough. ${ }^{19,23-25}$

The patient presented acute episode of tachydyspnea and sudden death on the postoperative period. The post-mortem examination confirmed the diagnosis of pulmonary thromboembolism.

Pulmonary thromboembolism is not the most common acute pulmonary complication among SCD patients, but it has to be remembered that $\mathrm{HbSC}$ disease's hypercoagulable state besides the orthopedic post-operatory facilitates the occurrence of thromboembolic events, even in young patients.

\section{CONCLUSION}

This autopsy case draws the attention to the the importance of early diagnosis and permanent treatment and control of sickle cell disease, which may lead to systemic involvement in youth, moreover to the importance of the hypercoagulability observed in these patients, particulary in situations of increased risk of thromboembolism such as the post-operatory. Description of the florid morphological aspects of this disease at autopsy is instructive and not well explored in the literature.

\section{REFERENCES}

1. Modell B, Darlison M. Global epidemiology of haemoglobin disorders and derived service indicators. Bull World Health Organ. 2008;86:480-7. PMid:18568278. PMCid:2647473. http://dx.doi.org/10.2471/BLT.06.036673

2. Weatherall DJ, Clegg JB. Inherited haemoglobin disorders: an increasing global health problem. Bull World Health Organ. 2001;79:704-12. PMid:11545326. PMCid:2566499.

3. Ataga KI, Key NS. Hypercoagulability in sickle cell disease: new approaches to an old problem. Hematology Am Soc Hematol Educ Program. 2007;91-6. PMid:18024615. http://dx.doi.org/10.1182/asheducation-2007.1.91

4. Felix AA, Souza HM, Ribeiro SBF. Epidemiologic and social aspects of sickle cell disease. Rev Bras Hematol Hemoter. 2010;32:203-8. http://dx.doi.org/10.1590/S151684842010005000072

5. Nagel RL, Fabry ME, Steinberg MH. The paradox of hemoglobin SC disease. Blood Rev. 2003;17,167-78.

6. Rees DC, Williams TN, Gladwin MT. Sickle-cell disease. Lancet. 2010;376:2018-31. http://dx.doi.org/10.1016/ S0140-6736(10)61029-X

7. Zhou Z, Behymer M, Guchhait P. Role of extracellular hemoglobin in thrombosis and vascular occlusion in patients with sickle cell anemia. Anemia. 2011;2011:918-6.

8. Powars DR, Hiti A, Ramicone E, Johnson C, Chan L. Outcome in hemoglobin SC disease: a four-decade observational study of clinical, hematologic, and genetic factors. Am J Hematol. 2002;70:206-15. PMid:12111766. http://dx.doi.org/10.1002/ajh.10140

9. Hebbel RP. Adhesive interactions of sickle erythrocytes with endothelium. J Clin Invest. 1997;100:S83-6. PMid:9413407

10. Koumbourlis AC, Lee DJ, Lee A. Lung function and somatic growth in patients with hemoglobin SC sickle cell disease. Pediatr Pulmonol. 2008;43:175-8. PMid:18085696. http://dx.doi.org/10.1002/ppul.20752

11. Stuart MJ, Nagel RL. Sickle-cell disease. Lancet. 2004;364:1343-60. http://dx.doi.org/10.1016/S0140-6736 (04)17192-4

12. Almeida A, Roberts I. Bone involvement in sickle cell disease. Br J Haematol. 2005;129:482-90. PMid:15877730. http://dx.doi.org/10.1111/j.1365-2141.2005.05476.x 
13. De Franceschi L. Pathophisiology of sickle cell disease and new drugs for the treatment. Mediterr J Hematol Infect Dis. 2009;20;1:e2009024.

14. Ataga KI, Eugene MBBS, Oringer P. Hypercoagulability in sickle cell disease: a curious paradox. Am J Med. 2003;115:721-8.

15. Austin H, Key NS, Benson JM, et al. Sickle cell trait and the risk of venous thromboembolism among blacks. Blood. 2007;110:908-12. http://dx.doi.org/10.1182/blood-200611-057604

16. Buchanan GR, DeBaun MR, Quinn CT, Steinberg MH. Sickle cell disease. Hematology. 2004;35-47. PMid:15561675. http://dx.doi.org/10.1182/asheducation-2004.1.35

17. Kepron C, Somers GR, Pollanen MS. Sickle cell trait mimicking multiple inflicted injuries in a 5-Year-Old Boy. J Forensic Sci. 2009;54:1141-5. PMid:19570047. http://dx.doi.org/10.1111/j.1556-4029.2009.01098.x

18. Ebert EC, Nagar M, Hagspiel KD. Intestinal and hepatic complications of sickle cell disease. Clin Gastroenterol Hepatol. 2010;8:483-9. PMid:20215064. http://dx.doi. org/10.1016/j.cgh.2010.02.016

19. Benkirane A, Berrebi D, Olaya N, et al. Hamartoma of the spleen (splenoma) in a child with sickle cell anemia.
Ann Pathol. 2007;27-30. http://dx.doi.org/10.1016/S02426498(07)88681-0

20. Jouni S, Sehili S, Mokrani A, et al. Splenic nodules and sickle cell anemia. Radiol. 2001;82:1637-41.

21. Elsayes KM, Narra VR, Mukundan G, Lewis Junior JS, Menias CO, Heiken JP. MR imaging of the spleen: spectrum of abnormalities. Radiographics. 2005;25:967-82. http://dx.doi.org/10.1148/rg.254045154

22. Manci EA, Culberson DE, Yang YM, et al. Causes of death in sickle cell disease: an autopsy study. $\mathrm{Br} \mathrm{J}$ Haematol. 2003;123:359-65.

23. Graham JK, Mosunjac M, Hanzlick RL, Mosunjac M. Sickle cell lung disease and sudden death. A retrospective/ prospective study of 21 autopsy cases and literature review. Am J Forensic Med Pathol. 2007;28:168-72. PMid:17525572. http://dx.doi.org/10.1097/01.paf.0000 257397.92466.50

24. Darbari DS, Faget PK, Kwagyan J, Rana S, Gourdeuk VR, Castro O. Circumstances of death in adult sickle cell disease patients. Am J Hematol. 2006;81:858-63.

25. Vichinsky EP, Styles LA, Colangelo LH, Wright EC, Castro O, Nickerson B. Acute chest syndrome in sickle cell disease: clinical presentation and course. Blood. 2004;89:1787-92.

\section{Conflict of interest: None.}

Submitted on: $9^{\text {th }}$ August 2011

Accept on: $18^{\text {th }}$ August 2011

Correspondence: Thiago Trolez Amancio

Rua das Calandrinas, 36 - Parque das Flores - Taubaté/SP - Brasil.

E-mail: thiagoamancio87@hotmail.com 